\title{
Effectiveness of various bioreactors for thraustochytrid culture and production (Aurantiochytruim limacinum BUCHAXM 122)
}

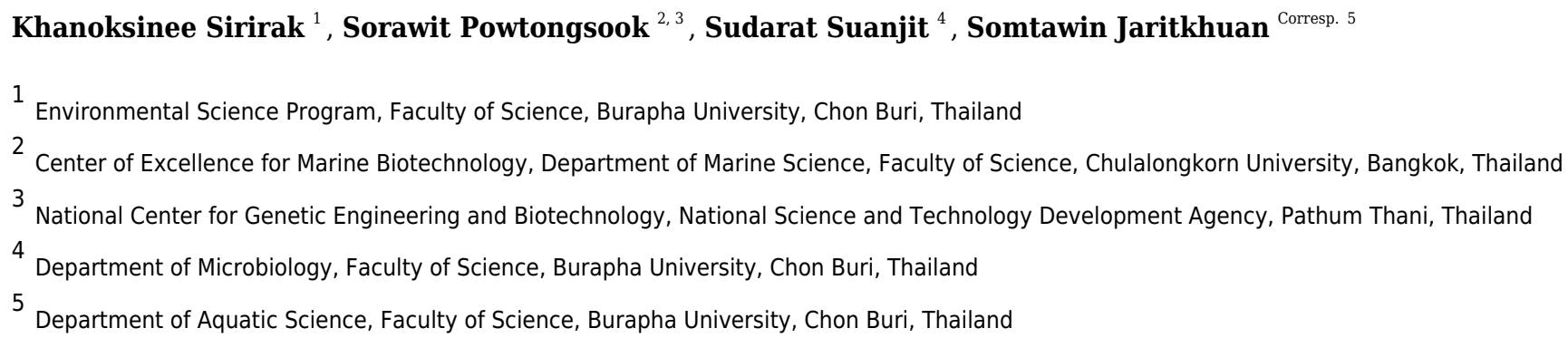

This study aimed to develop bioreactors for cultivation of thraustochytrid, Aurantiochytrium limacinum BUCHAXM 122, that are low in cost and simple to operate. Obtaining maximum biomass and fatty acid production was a prerequisite. Three bioreactor designs were used: stirred tank bioreactor (STB), bubble bioreactor (BB) and internal loop airlift bioreactor (ILAB). The bioreactors were evaluated for their influence on oxygen mass transfer coefficient $\left(\mathrm{k}_{\mathrm{L}} \mathrm{a}\right)$, using various spargers, mixing speed, and aeration rates. Biomass and DHA production from STB, BB, ILAB were then compared with an incubator shaker, using batch culture experiments. Results showed that a bundle of eight super-fine pore air stones was the best type of aeration sparger for all three bioreactors. Optimal culture conditions in STB were $600 \mathrm{rpm}$ agitation speed and $2 \mathrm{vvm}$ aeration rate, while $2 \mathrm{vvm}$ and $1.5 \mathrm{vvm}$ aeration provided highest biomass productivity in BB and ILAB, respectively. Antifoam agent was needed for all reactor types in order to reduce excessive foaming. Results indicated that with optimized conditions, these bioreactors are capable of thraustochytrid cultivation with a similar efficiency as cultivation using a rotary shaker. STB had the highest $k_{L} a$ and provided the highest biomass of $43.05 \pm 0.35 \mathrm{~g} / \mathrm{L}$ at $48 \mathrm{~h}$. BB was simple in design, had low operating costs and was easy to build, but yielded the lowest biomass $(27.50 \pm 1.56 \mathrm{~g} / \mathrm{L})$. ILAB, on the other hand, had lower $\mathrm{k}_{\mathrm{L}} \mathrm{a}$ than STB, but provided highest fatty acid productivity, of $35.36 \pm 2.51 \%$ TFA. 


\section{Effectiveness of various bioreactors for thraustochytrid culture and production (Aurantiochytruim limacinum BUCHAXM 122)}

Khanoksinee Sirirak ${ }^{1}$, Sorawit Powtongsook ${ }^{2,3}$, Sudarat Suanjit ${ }^{4}$, Somtawin Jaritkhuan ${ }^{5}$

${ }^{1}$ Environmental Science Program, Faculty of Science, Burapha University, Chon Buri, Thailand

${ }^{2}$ Center of Excellence for Marine Biotechnology, Department of Marine Science, Faculty of Science, Chulalongkorn University, Bangkok, Thailand

${ }^{3}$ National Center for Genetic Engineering and Biotechnology, National Science and Technology Development Agency, Pathum Thani, Thailand

${ }^{4}$ Department of Microbiology, Faculty of Science, Burapha University, Chon Buri, Thailand

${ }^{5}$ Department of Aquatic Science, Faculty of Science, Burapha University, Chon Buri, Thailand

Corresponding Author:

Somtawin Jaritkhuan ${ }^{5}$

Department of Aquatic Science, Faculty of Science, Burapha University, Chon Buri, 20131, Thailand

Email address: somtawin@buu.ac.th

\section{ABSTRACT}

This study aimed to develop bioreactors for cultivation of thraustochytrid, Aurantiochytrium limacinum BUCHAXM 122, that are low in cost and simple to operate. Obtaining maximum biomass and fatty acid production was a prerequisite. Three bioreactor designs were used: stirred tank bioreactor (STB), bubble bioreactor (BB) and internal loop airlift bioreactor (ILAB). The bioreactors were evaluated for their influence on oxygen mass transfer coefficient $\left(k_{L} a\right)$, using various spargers, mixing speed, and aeration rates. Biomass and DHA production from STB, BB, ILAB were then compared with an incubator shaker, using batch culture experiments. Results showed that a bundle of eight super-fine pore air stones was the best type of aeration sparger for all three bioreactors. Optimal culture conditions in STB were $600 \mathrm{rpm}$ agitation speed and 2 vvm aeration rate, while $2 \mathrm{vvm}$ and $1.5 \mathrm{vvm}$ aeration provided highest biomass productivity in BB and ILAB, respectively. Antifoam agent was needed for all reactor types in order to reduce excessive foaming. Results indicated that with optimized conditions, these bioreactors are capable of thraustochytrid cultivation with a similar efficiency as cultivation using a rotary shaker. STB had the highest $\mathrm{k}_{\mathrm{L}}$ a and provided the highest biomass of $43.05 \pm 0.35 \mathrm{~g} / \mathrm{L}$ at $48 \mathrm{~h}$. BB was simple in design, had low operating costs and was easy to build, but yielded the lowest 
36 biomass $(27.50 \pm 1.56 \mathrm{~g} / \mathrm{L})$. ILAB, on the other hand, had lower $\mathrm{k}_{\mathrm{L}}$ a than $\mathrm{STB}$, but provided

37 highest fatty acid productivity, of $35.36 \pm 2.51 \%$ TFA.

38

\section{INTRODUCTION}

40 Thraustochytrids are unicellular, eukaryote, heterotrophic, and obligate marine microorganisms.

41 They are widely distributed and play an important role as ecological decomposers in marine 42 environments (Marchan et al., 2018). They have the ability to produce high amounts of long43 chain polyunsaturated fatty acids (PUFAs), such as docosahexaenoic acid (DHA) and 44 docosapentaenoic acid (DPA), essential fatty acids for marine animals (Ryosuke \& Takeshi, 45 2015; Unagul et al., 2017; Jaritkhuan \& Suanjit, 2018). These fatty acids are also crucial for 46 human health and well-being (Horrocks \& Yeo, 1999; Osendarp, 2011; Asztalos et al., 2016).

47 Thraustochytrids can provide an alternative energy source, as through palmitic acid (PA), used in 48 biodiesel production (Lee Chang et al., 2013; Kim et al., 2013). Production of PUFAs using 49 thraustochytrids has been developed; thus, these organisms represent a promising and significant 50 source of PUFAs for biotechnological applications.

51 For mass culturing, thraustochytrids require a high oxygen mass transfer (Michelin et al., 2013 ) to produce primary metabolites during the growth phase (Qu et al., 2010). Oxygen is a key substrate for aerobic bioprocesses and has low solubility in aqueous solutions. Therefore, a continuous oxygen supply is needed and the oxygen transfer rate must be known to achieve an optimum design operation in batch bioreactors (Garcia-Ochoa \& Gomez, 2009; Chang et al., 2013). Bioreactors have already been developed for culturing microbial cells. Therefore, aerobic cell cultivation using bioreactors should be an effective approach to enhance mass production of thraustochytrids. However, optimizing an appropriate bioreactor will be key in achieving successful cultivation of this microorganism.

Currently, many different types of bioreactors are in use for cell culture, including stirred tank bioreactor (STB), bubble bioreactor (BB) and internal loop airlift bioreactor (ILAB). STB, the most widely-used bioreactor, is equipped with an impeller for homogenizing culture media and a sparger for delivering oxygen to the cells. STBs are primarily used to scale-up the culture process from a research and development scale to a manufacturing scale. BBs are basically cylindrical bioreactors, with a gas distributor at the bottom; whereby the gas is sparged, in the 
67 normally used for cell growth and oxygen supply; because it doesn't use a complex mixing

68 system, these reactors can be compact and have low operating and maintenance costs (Kantarci,

69 Borak \& Ulgen, 2005). ILAB is one type of bubble reactor, having an internal draft-tube that

70 promotes gas-liquid mass transfer and mixing (Saravanan, Pakshirajan \& Saha, 2008). Today's

71 bioreactors for mass culture of microorganisms are still expensive, even without automated

72 production control systems. In addition, knowledge is limited on thraustochytrid culture in these

73 bioreactor types.

74 Growth of $A$. limacinum is limited mostly by oxygen availability in the reactor.

75 Increasing oxygen mass transfer in bioreactors can enhance growth and fatty acids production of

76 A. limacinum to levels equivalent to a shaking flask (commonly used a reference). This research

77 was conducted in order to develop and modify a simple, low-cost bioreactor that is reliable and

78 easy to operate for mass production of the thraustochytrid A. limacinum BUCHAXM 122. Three

79 kinds of bioreactors, stirred tank bioreactor (STB), bubble bioreactor (BB) and internal loop

80 airlift bioreactor (ILAB) were modified for mass production of A. limacinum BUCHAXM 122,

81 and maximizing biomass and DHA production. The objectives of this research were to evaluate

82 the influence of various spargers, mixing rates, and aeration rates on oxygen mass transfer

83 coefficient $\left(\mathrm{k}_{\mathrm{L}} \mathrm{a}\right)$, and then to compare biomass and DHA production in STB, BB, ILAB and

84 incubator shaker in batch culture experiments. It should be of great interest for the

85 biopharmaceutical industry to further continue and develop more efficient cell cultivation

86 processes with higher product quality at lower manufacturing costs and simple operating

87 conditions.

88

89 MATERIALS AND METHODS

90 Experimental design

91 Three bioreactor types, stirred tank bioreactor (STB), bubble bioreactor (BB) and internal loop

92 airlift bioreactor (ILAB) were built and modified with the concept of low-cost and simple

93 operation. These improved bioreactors were then evaluated for their influence on oxygen mass

94 transfer coefficient $\left(\mathrm{k}_{\mathrm{L}} \mathrm{a}\right)$, using various spargers, mixing rates and aeration rates, then compared

95 with an incubator shaker (section 1, evaluated using distilled water without microorganisms).

96 Best conditions for cultivation of A. limacinum BUCHAXM 122 found in section 1 (maximum 
$97 \mathrm{k}_{\mathrm{L}} \mathrm{a}$ ) for each developed bioreactor were determined, and compared with standard incubator

98 shaker (section 2). A schematic overview of this study is summarized as Fig. 1.

99

100 Bioreactor configuration and operating conditions

101 In this study, three types of bioreactors were designed and operated using low cost materials:

102 stirred tank, bubble and internal loop airlift (Fig. 2). The stirred tank bioreactor (STB) was

103 modified from Wegrich \& Shurter (1953), Scragg (1991), and Stanbury, Whitaker \& Hall

104 (1995). Our STB consisted of a culture vessel made from a 2-L laboratory bottle (working

105 volume of $1 \mathrm{~L}$ ), four stainless steel baffles (each baffle $1.25 \mathrm{~cm}$ wide x $12.5 \mathrm{~cm}$ high, located 0.5

$106 \mathrm{~cm}$ away from the tank wall) and one set of disk turbines $(5 \mathrm{~cm}$ in diameter, with eight $0.9 \times 1$

$107 \mathrm{~cm}$ blades). The impeller shaft was made of a 30-cm carbon rod. Impeller rotation was controlled

108 by a microcontroller system (Arduino). Motor speed was regulated through a Proportional-

109 Integral-Derivative Controller (PID Controller). The aeration system consisted of a sparger

110 installed under the impeller. Air inlet-outlet and sampling tubes were installed at the top of the

111 bioreactor (Fig. 2A).

112 The bubble bioreactor (BB) was constructed using a 2-L laboratory bottle with a working

113 volume of $1 \mathrm{~L}$. The culture vessel was $13 \mathrm{~cm}$ in diameter and $21 \mathrm{~cm}$ in height. Its aeration system

114 consisted of a sparger bundle located at the bottom of the reactor. The sparger provided uniform

115 aeration throughout the vessel. Air inlet, outlet and sampling tubes were installed, similar to the 116 STB (Fig. 2B).

117 The internal loop airlift bioreactor (ILAB) was redesigned with modification from Cerri $118 \&$ Badino (2010). The culture vessel was $9 \mathrm{~cm}$ in diameter and $45 \mathrm{~cm}$ in height, with a working 119 volume of $2 \mathrm{~L}$. The internal draft tube was made of borosilicate glass with $26 \mathrm{~cm}$ height and 5 $120 \mathrm{~cm}$ diameter. Aeration was provided through a sparger bundle at the bottom. Air was bubbled 121 from the bottom through the draft tube (riser), creating water flow downward through the 122 downcomer channel, between the draft tube and outer wall (Fig. 2C).

123 Air purification was performed using a series of two filters $(0.3 \mu \mathrm{m}$ diameter polyethylene 124 filter and a $0.2 \mu \mathrm{m}$ diameter filter) and 12-watt UV lamp. The filters and UV lamp were 125 connected by a silicone tube. Prior to operation, the tube outlet end from each bioreactor was 126 immersed in 1,000 ppm copper (II) sulfate pentahydrate $\left(\mathrm{CuSO}_{4} \cdot 5 \mathrm{H}_{2} \mathrm{O}\right)$ to prevent outside 
127 contamination (Reyes-Jara et al., 2016) (Fig. 3). Aeration rate was controlled by Rotameter

128 (Dwyer, Michigan City, Indiana, USA).

129

130 Investigation of oxygen mass transfer

131 Effects of sparger configuration on oxygen mass transfer efficiency

132 Six sparger configurations for aeration were investigated for oxygen mass transfer capability in

133 the bioreactors: 1) silicone tube with $4 \mathrm{~mm}$ internal diameter, without sparger (control), 2)

134 spherical coarse-bubble air stone, 3) spherical fine-bubble air stone, 4) four spherical fine-bubble

135 air stones, 5) four cylindrical super-fine bubble air stones and 6) eight cylindrical super-fine

136 bubble air stones (Fig. 4). The coarse and fine air stones were $25 \mathrm{~mm}$ in diameter with pore size

137 of 200-500 $\mu \mathrm{m}$ and $150-300 \mu \mathrm{m}$, respectively, while the cylindrical air stones were $10 \mathrm{~mm}$ in

138 diameter and $20 \mathrm{~mm}$ in length, with a pore size of 10-20 $\mu \mathrm{m}$. These air stones are widely used in

139 aquariums. Oxygen mass transfer capability by spargers was indicated by volumetric mass

140 transfer coefficient $\left(\mathrm{k}_{\mathrm{L}} \mathrm{a}\right)$. $\mathrm{k}_{\mathrm{L}}$ a value was measured in all bioreactors using distilled water, and

141 then compared to the value obtained for an incubator shaker (GALLENKAMP, UK), using 250-

$142 \mathrm{ml}$ Erlenmeyer flasks agitated at $200 \mathrm{rpm}$. Testing was performed using five trials. $\mathrm{k}_{\mathrm{L}} \mathrm{a}$ was

143 measured using a DO meter (YSI 550A, steady-state Clark type polarographic, USA) at room

144 temperature, with zero oxygen water generated by the sulfite method (modified from Puskeiler \&

145 Weuster-Botz, 2005; Bouaifi, et al., 2001). Atmospheric air containing approximately 21 percent

146 oxygen was then introduced into all bioreactors and shakers. All dissolved oxygen measurements

147 were continuously measured from zero oxygen concentration until they reached saturation

148 (average 7.04 $\pm 0.16 \mathrm{ppm}$ ). Data collection was performed by video recording of the DO meter

149 display. During measurement of dissolved oxygen in the shaker, the flask was locked to the

150 shaking platform and the oxygen probe was securely fixed with cotton wrapped in foil and

151 masking tape at the mouth of the flask, with the tip not touching the flask bottom. In STB and

152 BB reactors, the oxygen probe was located at the bottom of the tank, with the tip not touching the

153 bottom. For the ILAB, the oxygen probe was affixed to the middle of the riser.

The $\mathrm{k}_{\mathrm{L}} \mathrm{a}$ value was measured by employing the dynamic method (non-fermentative 
158 (OTR) and the oxygen uptake rate (OUR) of a growing cell were described by the following 159 equations, (Eq. 1-3). These relationships represent one of the foundations of bioreactor design. 160

161

162

163

164

165

166

167

168

169

170

171

172

173

174

175

176

177

178

179

180

181

182

183

184

185

186

$$
\begin{aligned}
& \frac{\mathrm{dC}}{\mathrm{dt}}=\text { OTR }- \text { OUR } \\
& \text { OTR }=\mathrm{k}_{\mathrm{L}} \mathrm{a}\left(\mathrm{C}_{\mathrm{s}}-\mathrm{C}\right)
\end{aligned}
$$

Substituting Eq. (2) into Eq. (1) results in

$$
\frac{\mathrm{dC}}{\mathrm{dt}}=\mathrm{k}_{\mathrm{L}} \mathrm{a}\left(\mathrm{C}_{\mathrm{s}}-\mathrm{C}\right)-\text { OUR }
$$

where $\mathrm{C}_{\mathrm{s}}$ is the saturated oxygen concentration in the liquid phase, and $\mathrm{C}$ is the DO concentration, $\mathrm{OUR}=0$. Integration of Eq. (3) from $\mathrm{C}_{0}$ to $\mathrm{C}$ gives:

$$
\ln (\mathrm{Cs}-\mathrm{C}) /(\mathrm{Cs}-\mathrm{C} 0)=-\mathrm{kLa} \cdot \mathrm{t}
$$

where $\mathrm{C}_{0}$ is the initial DO concentration of dissolved oxygen at $\mathrm{t}=0$,

The $\mathrm{k}_{\mathrm{L}}$ a value was calculated from slope by plotting $\ln \left(\mathrm{C}_{\mathrm{s}}-\mathrm{C}\right) /\left(\mathrm{C}_{\mathrm{s}}-\mathrm{C}_{0}\right)$ against time according to the equation. The $\mathrm{k}_{\mathrm{L}}$ a obtained was calculated from the linear slope of oxygen increase during aeration. These measurements were performed for around 30-90 seconds for all treatments. Calculation of $\mathrm{k}_{\mathrm{L}} \mathrm{a}$ was based on the principle that R-squared is closest to 1 .

In STB, all sparger types were tested, using an agitation speed of $450 \mathrm{rpm}$ and aeration rate of 3 vvm (Chang et al., 2014). In BB and ILAB, all sparger configurations were tested with 3 vvm aeration (Özcan, Sargin \& Göksungur 2014). The bundle of four fine-bubble air stones was not investigated in ILAB, because the space under the draft tube was too small.

\section{Effects of agitation speed and aeration rate on oxygen mass transfer efficiency}

The experiment was performed using sparger types that provided highest $\mathrm{k}_{\mathrm{L}} \mathrm{a}$ from the previous experiment. Bioreactor aeration was further evaluated with different agitation speeds and aeration rates. Agitation speeds tested in STB were 450 and $600 \mathrm{rpm}$ (Chang et al., 2013; Chang et al., 2014), in combination with aeration rates of 0.5, 1, 2 and $3 \mathrm{vvm}, \mathrm{BB}$ and ILAB were operated at identical aeration rates. 
187 Cultivation of $A$. limacinum BUCHAXM 122 in bioreactors

188 Stock culture and inoculation of A. limacinum BUCHAXM 122

189 A. limacinum BUCHAXM 122 was isolated from mangrove forests located in the Mangrove

190 Resources Development Station 2, Tha Son, Chanthaburi Province, Thailand. A. limacinum

191 BUCHAXM 122 inoculum was prepared in $250 \mathrm{~mL}$ Erlenmeyer flasks containing $50 \mathrm{~mL}$ of

192 GYP liquid medium, composed of $60 \mathrm{~g} / \mathrm{L}$ glucose, $10 \mathrm{~g} / \mathrm{L}$ yeast extract and $10 \mathrm{~g} / \mathrm{L}$ peptone in 15

193 PSU seawater. Cultures were incubated at $25^{\circ} \mathrm{C}$ with shaking $(200 \mathrm{rpm}$ ) for $48 \mathrm{~h}$, before being

194 used as the inoculum.

195

196

Comparison of bioreactor types for A. limacinum BUCHAXM 122 cultivation

197 Five percent (5\%, v/v) A. limacinum BUCHAXM 122 inoculum was transferred and cultured in 198 each bioreactor, using GYP medium with the optimum sparger type, aeration rate and agitation 199 speed obtained from previously described experiments. Shaking flask cultures were carried out

200

201

202

203

204

205

206

207

208

209

210

211

212

213

214

215

216

in $250 \mathrm{~mL}$ Erlenmeyer flasks containing $50 \mathrm{~mL}$ of GYP medium with $200 \mathrm{rpm}$ agitation, then assigned as the control. All experiments were performed in duplicate. Cell samples were collected every $24 \mathrm{~h}$ throughout the 168 -h cultivation period, to determine biomass and DHA production. Dissolved oxygen was measured by DO meter (YSI 550A). Reduced sugar was determined by the dinitrosalicylic acid (DNS) method (Miller, 1959).

Dry biomass was determined by sampling $2 \mathrm{~mL}$ culture media from each bioreactor or culture flask, using sterile procedures. Samples were filtered through Whatman GF/C (1.2 $\mu \mathrm{m})$ and rinsed with PBS solution. Filtered cells were then freeze dried at $-80^{\circ} \mathrm{C}$ (using freeze-dryer Heto LyoLab 3000, Heto-Holten A/S, Allerød, Denmark), and weighed. Average dry cell weight was plotted on a growth curve. Direct transmethylation (modified from Shimizu et al., 1988) was performed in order to analyze fatty acid composition of A. limacinum BUCHAXM 122.

Extracted fatty acid methyl esters (FAME) were analyzed using gas chromatograph (HP 6890

Series GC System, Wilmington, DE, USA) equipped with a flame ionization detector (FID) and fitted with a column using capillary column HP-INNO Wax polyethylene glycol (60 m x $250 \mu \mathrm{m}$ $\mathrm{x} 0.25 \mu \mathrm{m}$ ). Initial temperature was $50^{\circ} \mathrm{C}$ for 1 minute, increasing at a rate of $50{ }^{\circ} \mathrm{C} /$ minute to $200{ }^{\circ} \mathrm{C}$, holding for 1 minute, then increasing by $2{ }^{\circ} \mathrm{C}$ /minute to $210^{\circ} \mathrm{C}$, and holding for 14 minutes. Helium was used as the carrier gas. Both detector and injector temperatures were set at 
$217250^{\circ} \mathrm{C}$. Fatty acid content was calculated according to peak area of the chromatogram, in 218 accordance with the internal standard (nonadecanoic acid, 19:0, Fluka, Buchs, Switzerland). 219 220

\section{Statistical analysis}

222

Data were evaluated using one-way analysis of variance (ANOVA) and LSD for post hoc comparisons, at a confidence level of $5 \%(p<0.05)$. Multiple linear regression (MLR) was

223 performed with the stepwise method in order to show relationships between $\mathrm{k}_{\mathrm{L}} \mathrm{a}$ and specific 224 growth rate, productivity, and sugar consumption.

225

226

\section{RESULTS}

227

Effect of sparger configuration on oxygen mass transfer capability

228

As shown in Fig. 5, aeration through a bundle of eight super-fine air stones resulted in the

229 highest $\mathrm{k}_{\mathrm{L}}$ a value for STB $\left(123.66 \pm 15.47 \mathrm{~h}^{-1}\right)$, BB $\left(122.99 \pm 21.04 \mathrm{~h}^{-1}\right)$ and ILAB $(123.53 \pm$ $\left.4.57 \mathrm{~h}^{-1}\right)$. $\mathrm{k}_{\mathrm{L}}$ a values for eight super-fine air stones in STB and BB were significantly higher than 231 for other spargers. $\mathrm{k}_{\mathrm{L}} \mathrm{a}$ values were similar for all air stone configurations in ILAB. Using optimized conditions, the $\mathrm{k}_{\mathrm{L}}$ a values obtained from eight super-fine air stones were not significantly different $(p>0.05)$ from Erlenmeyer flasks in the rotary shaker at 200 rpm (132.98 234 $\left.\pm 18.75 \mathrm{~h}^{-1}\right)($ Table S1).

235

Effects of agitation speed and aeration rate on oxygen mass transfer

237

238

239

240

241

242

243

244

245

246

247

$\mathrm{k}_{\mathrm{L}}$ a values in all bioreactors increased with increasing aeration rate (Table 1). An aeration rate of $3 \mathrm{vvm}$ in BB and ILAB resulted in significantly higher $\mathrm{k}_{\mathrm{L}}$ a values than with other rates $(\mathrm{p}<$ $0.05)$. In STB, the highest $\mathrm{k}_{\mathrm{L}}$ a value of $155.92 \pm 18.52 \mathrm{~h}^{-1}(\mathrm{p}<0.05)$ was found at $600 \mathrm{rpm}$ with $3 \mathrm{vvm}$; however, there were no significant differences in $\mathrm{k}_{\mathrm{L}}$ a values using aeration rates of 2 and $3 \mathrm{vvm}$ or agitation speeds of 450 and $600 \mathrm{rpm}(\mathrm{p}>0.05)$.

\section{Growth and biomass production of $A$. limacinum BUCHAXM 122 in bioreactors}

When all bioreactors culturing A. limacinum BUCHAXM 122 were aerated at a high rate, i.e., 3 $\mathrm{vvm}$, there was a problem with foam formation on top of the culture medium. Therefore, the experiment was repeated with reduced aeration rates of $2 \mathrm{vvm}$ for STB and BB and $1.5 \mathrm{vvm}$ for ILAB in combination with $0.49 \%$ polypropylene glycol (SIGMA-ALDRICH) antifoaming agent. 
248 Biomass in STB peaked within $48 \mathrm{~h}(43.05 \pm 0.35 \mathrm{~g} / \mathrm{L})$; thereafter, the biomass decreased and 249 remained stable from $96-120 \mathrm{~h}(30.70 \pm 1.84-30.65 \pm 1.20 \mathrm{~g} / \mathrm{L})$, with $2.07 \pm 0.12 \mathrm{~g} / \mathrm{L}$ reducing 250 sugar residue. For ILAB, biomass rapidly increased within $48 \mathrm{~h}(35.50 \pm 1.84 \mathrm{~g} / \mathrm{L})$, after which it 251 slowly and continuously increased until $120 \mathrm{~h}(37.60 \pm 3.82 \mathrm{~g} / \mathrm{L})$, with $3.61 \pm 2.67 \mathrm{~g} / \mathrm{L}$ reducing 252 sugar residue. For the shaker, biomass rapidly increased within $48 \mathrm{~h}(29.55 \pm 1.77 \mathrm{~g} / \mathrm{L})$; after that 253 the biomass slowly increased between $72 \mathrm{~h}-120 \mathrm{~h}(31.30 \pm 0.28-32.90 \pm 0.28 \mathrm{~g} / \mathrm{L})$, with $2.04 \pm$ $2540.46 \mathrm{~g} / \mathrm{L}$ sugar residue. BB yielded the lowest biomass, rapidly increasing at $24-48 \mathrm{~h}$, then slowly 255 and continuously increasing until $120 \mathrm{~h}(38.55 \pm 4.60 \mathrm{~g} / \mathrm{L})$, with $41.87 \pm 0.10 \mathrm{~g} / \mathrm{L}$ reducing sugar 256 residue. Highest biomass and residual glucose for each bioreactor are shown in Fig. 6.

257 Comparing all bioreactors at $48 \mathrm{~h}$, the highest biomass was for STB, which had significantly 258 higher yields $(\mathrm{p}<0.05)$ than ILAB, shaker, and BB. Sugar was nearly depleted at the end of the 259 experiment in STB, ILAB and the shaker, but not for BB (Table S2).

260 Highest DHA production was obtained from ILAB at $120 \mathrm{~h}(199.02 \pm 0.41 \mathrm{mg} / \mathrm{g} \mathrm{DW}$, 261 $35.36 \pm 2.51 \%$ TFA). However, there was no significant difference in DHA production when 262 comparing this treatment to ILAB at $72 \mathrm{~h}(189.95 \pm 9.98 \mathrm{mg} / \mathrm{g} \mathrm{DW}, 36.93 \pm 0.64 \%$ TFA), ILAB 263 at $96 \mathrm{~h}(189.77 \pm 7.65 \mathrm{mg} / \mathrm{g} \mathrm{DW}, 38.15 \pm 0.70 \% \mathrm{TFA})$, and the shaker at $96 \mathrm{~h}(190.50 \pm 10.64$ 264 mg/g DW, $35.15 \pm 2.31 \%$ TFA) (p > 0.05) (Fig. 7, Table S3). Initial DO in the culture medium 265 was $0.03 \pm 0.01 \mathrm{mg} / \mathrm{L}$. DO values at the end of fermentation in STB $(8.20 \pm 0.09 \mathrm{mg} / \mathrm{L})$ and 266 267 $\operatorname{ILAB}(8.23 \pm 0.36 \mathrm{mg} / \mathrm{L})$ were significantly higher than in the shaker $(6.59 \pm 0.08 \mathrm{mg} / \mathrm{L})$ and $\operatorname{BCB}(6.95 \pm 0.16 \mathrm{mg} / \mathrm{L})$.

A further experiment was conducted, reducing aeration rates to $0.1 \mathrm{vvm}$ for all bioreactors and the shaker, and without addition of anti-foaming agent. Highest biomass was observed in STB $(25.00 \pm 0.99 \mathrm{~g} / \mathrm{L})$, showing no significant difference from the shaker $(24.40 \pm$ $0.85 \mathrm{~g} / \mathrm{L})$ or ILAB $(23.41 \pm 0.29 \mathrm{~g} / \mathrm{L})(\mathrm{p}>0.05)$. Biomass in STB was significantly higher than $272 \mathrm{BB}(21.15 \pm 1.48 \mathrm{~g} / \mathrm{L})(\mathrm{p}<0.05)$. Moreover, there were no significant differences in DHA 273 production among the shaker, STB and ILAB ( $p>0.05)$ (Table 2). STB, shaker and ILAB 274 consumed more glucose than BB. However, at the end of the experiment, glucose was not 275 completely consumed in any of the treatments (Fig. 6, Table S4). $0.01 \mathrm{mg} / \mathrm{L}), \mathrm{STB}(6.48 \pm 0.02 \mathrm{mg} / \mathrm{L}, 6.45 \pm 0.06 \mathrm{mg} / \mathrm{L})$ and ILAB $(6.45 \pm 0.05 \mathrm{mg} / \mathrm{L}, 5.95 \pm$ 
$2780.21 \mathrm{mg} / \mathrm{L})$ were quite similar, while DO for BB $(4.99 \pm 0.05 \mathrm{mg} / \mathrm{L}, 1.03 \pm 0.11 \mathrm{mg} / \mathrm{L})$, was 279 significantly lower.

280 Comparison between $\mathrm{k}_{\mathrm{L}} \mathrm{a}$ and aeration rate revealed that aeration rates in $\mathrm{STB}$ and $\mathrm{BB}$ at

$2812 \mathrm{vvm}$ and in ILAB at $3 \mathrm{vvm}$ resulted in $\mathrm{k}_{\mathrm{L}}$ a values equivalent to that in the shaker (Fig. 8).

282 Multiple regression analysis results showed that specific growth rates of $A$. limacinum

283 BUCHAXM 122 was positively correlated with the $\mathrm{k}_{\mathrm{L}}$ a value.

284

285 DISCUSSION

286 Bioreactor configuration and operating conditions

287 Advantages of using STB, BB and ILAB bioreactors for microbial production have been 288 reported in previous studies (Stanbury, Whitaker \& Hall 1995; Cerri \& Badino, 2010). The 289 noteworthy feature of STB is that the sparger is placed under the impeller, producing the highest

$290 \mathrm{k}_{\mathrm{L}}$ a value and resulting in a high biomass. The STB, although widely used in biological

291 production, is well known to have shearing problems, which can cause cell damage (Kim, Kang

$292 \&$ Lee, 1997). In this study, the BB design was modified by using 2-L laboratory glass bottles. It

293 has low maintenance costs and reduces overall cost of oxygen delivery by 10-20 percent, relative 294 to the STB (Humbrid, Davis \& McMillan, 2017). However, in this study, its simplified design 295 caused sedimentation in the culture vessel, resulting in the lowest biomass production. This was 296 due to the combined effects of the culture media flow properties and the gas content, which 297 relates back to the diameter of the reactor (Kantarci, Borak \& Ulgen, 2005).

298 Results of this study showed that ILAB had a lower $\mathrm{k}_{\mathrm{L}}$ a value than STB; on the other 299 hand, liquid circulation and mixing was better than in BB. ILAB is generally used in applications 300 involving low viscosity fluids, not requiring mechanical agitation, and providing low shear 301 forces (Fontana, Polidoro \& da Silveira, 2009). This study suggests that ILAB might suitably 302 support high fat microbial culture. For instance, the ILAB bioreactor has been used to cultivate 303 oleaginous yeast Rhodotorula glutinis (Yen \& Liu, 2014). However, ILAB has limited capability 304 when used in high aeration applications (Qu et al., 2010) due to foam formation. Reduced 305 aeration rates and lower oxygen mass transfer might affect the oxygen availability for cell 306 growth. 
309 This study shows that the bundle of eight super-fine air stones was the best sparger type for all

310 three bioreactors, since it produced a $\mathrm{k}_{\mathrm{L}}$ a value equivalent to the standard $200 \mathrm{rpm}$ rotary shaker

$311\left(132.98 \pm 18.75 \mathrm{~h}^{-1}\right)$. The $\mathrm{k}_{\mathrm{L}}$ a value measured from rotary shaker was similarly to the $\mathrm{k}_{\mathrm{L}} \mathrm{a}$ value

$312\left(108-180 \mathrm{~h}^{-1}\right)$ obtained by shaking in a 50-ml sodium sulfite system at 120-200 rpm (Kato et al.,

313 2005). The super-fine pores provide numerous small air bubbles, with uniform distribution by

314 using eight stones, leading to a homogeneous flow. This homogeneous flow facilitates the

315 biochemical reactions involved in oxygen utilization and mass transfer of oxygen to cells

316 (Garcia-Ochoa et al., 2010), while larger bubbles lead to coalescing and unsteady heterogeneous

317 flow creation (Hoseinkhani et al., 2019). Results of this study are consistent with a previous

318 report, which found that increasing surface area of the sparger and number of pores resulted in

319 higher $\mathrm{k}_{\mathrm{L}} \mathrm{a}$ (De Wilde et al., 2014) by improving bubble dispersion, preventing bubble overflow

320 and reducing gas flow rate. Similarly, cultivation of Schizochytrium sp. using a microbubble-type

321 sparger was found to have 8.6-fold higher $\mathrm{k}_{\mathrm{L}}$ a values than with a general type sparger ( $J u$ et al.,

322 2019). However, it was also based on the pore size of sparger; if the pore size is too large, the

$323 \mathrm{k}_{\mathrm{L}}$ a difference may not be seen. For instance, the $\mathrm{k}_{\mathrm{L}} \mathrm{a}$ value was not significantly different when

324 using spargers with different numbers of holes (1, 4, and 9) and hole diameters (6, 3 and $2 \mathrm{~mm})$

325 (Karimi et al., 2013). Conversely, the sparger affects bubble size, and bubble size is specific to

326 certain oleaginous microalgae culturing. For instance, culturing Crypthecodinium cohnii in BB

327 using bubbles of $0.18 \mathrm{~cm}$ diameter resulted in higher biomass than bubbles of 0.09 and $0.36 \mathrm{~cm}$

328 diameter. However, the $0.36 \mathrm{~cm}$ bubbles gave highest DHA production, followed by 0.18 and

$3290.09 \mathrm{~cm}$, respectively (Hoseinkhani et al., 2019). This indicates that there is an optimal bubble

330 size leading to growth and production of healthy fatty acids. For this reason, further studies to

331 find the appropriate sizing of air bubbles for A. limacinum BUCHAXM 122 production should

332 be initiated.

333

334 Effect of agitation speed and aeration rate on oxygen mass transfer

335 This study shows that increasing agitation speed and aeration rate resulted in higher $\mathrm{k}_{\mathrm{L}} \mathrm{a}$ values.

336 Similar results have been reported for a 30-L STB system; when agitation speed was increased

337 from $300 \mathrm{rpm}$ and $0.6 \mathrm{~m}^{3} / \mathrm{h}$ to $600 \mathrm{rpm}$ and $2 \mathrm{~m}^{3} / \mathrm{h}, \mathrm{k}_{\mathrm{L}}$ a value increased from $143 \pm 19 \mathrm{~h}^{-1}$ to

$3381,802 \pm 105 \mathrm{~h}^{-1}$ (Chang et al., 2013). In addition, higher agitation speeds (400-800 rpm) with 1-3

$339 \mathrm{~L} / \mathrm{m}^{3}$ have been found to be the most efficient for oxygen mass transfer in STB. Similar results

Peer] reviewing PDF | (2020:10:54555:1:0:NEW 14 Mar 2021) 
340 have been reported for agitation speeds of 450 and $600 \mathrm{rpm}$, with aeration rate of 1-3 vvm

341 (Karimi et al., 2013). Agitation rates below $300 \mathrm{rpm}$ resulted in insufficient agitation to capture

342 air bubbles in the bioreactor, and consequently may limit mass transfer of oxygen. Our data show

343 that aeration rate has an effect on the $\mathrm{k}_{\mathrm{L}}$ a value in ILAB and BB, as well. Likewise, in the

344 cultivation of Rhodotorula glutinis in ILAB, it was found that $\mathrm{k}_{\mathrm{L}}$ a value increased with aeration

345 rate $(1.0,1.5,2.0$ and $2.5 \mathrm{vvm})$, and the aeration rate at 1.5-2.5 vvm was able to provide high

346 biomass and fatty acid yields (Yen \& Liu., 2014). Higher $\mathrm{k}_{\mathrm{L}}$ a values have also been obtained in

347 bubble column bioreactor (BCB) by increasing the aeration rate (Kumar \& Vinod, 2014).

348 Effects of agitation speed and aeration rate on $\mathrm{k}_{\mathrm{L}} \mathrm{a}$ can be explained by the relation of

349 stirrer speed and specific interfacial area values in STB, and by bubble size in all bioreactor

350 types. Therefore, speed of the stirrer and mixing play an important role in breaking up the air

351 bubbles. Also, turbulence and shear are caused by baffles (Kawase \& Moo-Young, 1990; Garcia-

352 Ochoa \& Gomez, 2009). Air bubble dispersion is also related to gas dispersion, gas hold-up and

353 residence time (Joshi, Pandit \& Sharma, 1982; Barigou \& Greaves, 1996; Garcia-Ochoa \&

354 Gomez, 2009). Dispersion is also related to other factors, such as liquid properties, gas velocity,

355 gas injection rate, operating pressure, injection tube diameter and column diameter (Kawase,

356 Halard \& Moo-Young, 1992; Garcia-Ochoa \& Gomez, 2009; Garcia-Ochoa et al., 2010;

357 Mohagheghian \& Elbing, 2018).

358

359 Biomass and DHA production of $A$. limacinum BUCHAXM 122 in bioreactors

360 Production of A. limacinum BUCHAXM 122 in STB showed faster growth and higher biomass

361 yield than in the rotary shaker, ILAB and BB. These findings are consistent with batch

362 fermentation of Aspergillus oryzae in STB, with agitation rates of 200-700 rpm and aeration

363 rates of $0.5-2.5 \mathrm{vvm}(14.1 \pm 0.13 \mathrm{~g} / \mathrm{L})$ which is higher than ILAB at $0.5-2.5 \mathrm{vvm}(10.1 \pm 0.03$

$364 \mathrm{~g} / \mathrm{L}$ ) (Fontana, Polidoro \& da Silveira, 2009). In general, increases in $\mathrm{k}_{\mathrm{L}}$ a lead to more biomass

365 production (Hoseinkhani et al., 2019). This is due to oxygen demand, particularly in the ATP

366 production process. Cell density increases rapidly during the exponential phase, producing a

367 large number of primary substances (primary metabolites), such as enzymes, nucleic acids and

368 other proteins from ATP by aerobic respiration (Qu et al., 2010). Conversely, when DO

369 concentrations decrease, metabolic rate of microorganisms displays a significant decrease (Sinha,

370 Dautz \& Hader, 2001). From experiments with an STB system, fed-batch cultures of 
371 Schizochytrium sp. S31 with agitation rates of 300, 450 and $600 \mathrm{rpm}$ revealed that $600 \mathrm{rpm}$

372 provided highest oxygen uptake rates and yielded the highest biomass (Chang et al., 2014).

373 These findings are consistent with our study. Comparing two other bioreactors, Özcan, Sargin \&

374 Göksungur (2014) demonstrated that Aureobasidium pullulans produced higher biomass from

$375 \mathrm{ILAB}$, with aeration rates at $1 \mathrm{vvm}$ than from $\mathrm{BCB}$ at $0.2,1.1$ and $2 \mathrm{vvm}$.

376 According to a previous study, cell growth $(\mu ; 0.090 / \mathrm{h}$ ) and glucose consumption rate (qs;

$3770.115 / \mathrm{h})$ in airlift-type bioreactors were higher than from fermentation in stirrer-type vessels

$378(0.057 / \mathrm{h}$ and $0.064 / \mathrm{h}$, respectively) (Hong et al., 2013). Our results clearly indicate that biomass

379 production from bioreactors is related to glucose consumption. The highest biomass was in STB,

380 which also had the highest glucose consumption. BB, on the other hand, yielded the lowest

381 biomass, with its glucose consumption being lower than the other bioreactors and the rotary

382 shaker. This shows that efficiency of the bioreactor affects the remaining glucose in the reactor;

383 with glucose remaining in a reactor tank being the starting point for further development of

384 suitable culture media recipes. In addition, cell culture techniques in the log phase and reduction

385 of oxygen during the stationary phase of fatty acid production should be further developed ( $Q u$ et 386 al., 2010; Rosa et al., 2010).

387 One of the limitations of using a high aeration rate is that it produces large amounts of 388 foam. In our cultures of A. limacinum BUCHAXM 122, higher biomass was obtained at $2 \mathrm{vvm}$ 389 in STB and BB and at $1.5 \mathrm{vvm}$ in ILAB. However, if an antifoaming agent is required to avoid 390 overflowing, it can cause a decrease in $\mathrm{k}_{\mathrm{L}}$ a values (Sundaramurthy, Srivastava \& Mishra, 2011). 391 Consequently, cell cultivation in STB could be carried out at aeration rates of $0.1 \mathrm{vvm}$, since 392 biomass concentrations for $72 \mathrm{~h}(25.00 \pm 0.99 \mathrm{~g} / \mathrm{L})$ were similar to the shaker $(22.35 \pm 3.89 \mathrm{~g} / \mathrm{L})$, 393 and were higher than the range of values reported for A. limacinum (range of 9.39-20.71 g/L) 394 (Jaritkhuan \& Suanjit, 2018).

395 DHA production obtained from ILAB and the rotary shaker were relatively similar in 396 yield. Highest DHA content in ILAB with $1.5 \mathrm{vvm}$ aeration rate was significantly higher than 397 both STB and BB. It was found that high agitation speeds negatively impacted DHA production 398 in STB. As reported by Chang et al. (2014) for Schizochytrium sp. S31, an agitation speed of 600 $399 \mathrm{rpm}$ produced lower DHA (29.37 $\pm 0.89 \%$ TFA) than $300 \mathrm{rpm}(36.04 \pm 1.78 \%$ TFA). Our 400 experiments also showed that using an agitation speed of $600 \mathrm{rpm}$, STB produced lower DHA 401 yield than other bioreactor types. 
402

403

404

405

406

407

408

409

410

411

412

413

414

415

416

417

418

419

420

421

422

423

424

425

426

427

428

429

430

431

432

It is known that microbial cells are sensitive to mechanical shear stress, particularly from high agitation intensity, as it causes cell damage (Wase et al., 1985; Hong et al., 2013). The cell wall of thraustochytrid organisms is non-cellulosic and thin, ranging from 2 to $3 \mathrm{~nm}$ thick (Marchan et al., 2018), and can be affected by relatively high shear stress, consistent with the report by Wang \& Lan (2018). In addition, cells with flagella are more shear sensitive than unicellular algae cells (Wang \& Lan, 2018). Thraustochytrids can move during the zoospore stage using two flagella. They may be affected by shear, resulting in less fatty acid production, since zoospores also store fatty acids (Morita et al., 2006).

A low aeration rate is more favorable for efficient DHA synthesis (Qu et al., 2010; Hoseinkhani et al., 2019). This study demonstrates that low aeration rates, i.e., 0.1 vvm, provide highest DHA yield during late stationary phase $(168 \mathrm{~h})$ in all bioreactors. ILAB, operated under low aeration rate (with less shear stress), may be an appropriate choice for DHA production. High oxygen content during the cell stage accumulates fatty acids, allowing cells to use carbon sources (glucose) in the breathing process and metabolism, rather than being used in lipid accumulation processes. The appropriate amount of primary metabolite production by oxygen limitation produces a sufficient quantity of Acetyl-CoA (a precursor to the synthesis of fatty acids). This also results in higher cell accumulation of fatty acids. Therefore, the DHA content in thraustochytrids depends on both amount of biomass (log and early stationary phase) and production of fatty acids (stationary phase). According to this study, both ILAB and shaker have lower shear forces than STB, which has a positive effect on maintaining cellular integrity. The cells are not damaged, resulting in a high DHA content. Moreover, the results show that $\mathrm{k}_{\mathrm{L}} \mathrm{a}$ value in ILAB was relatively lower than in the shaker. It is also associated with synthesis of fatty acids for each strain of thraustochytrid, as a pathway of with or without oxygen, to comply with the in-cell enzyme system (Jakobsen et al., 2008).

Higher DHA production may be related to the activity of anaerobic fatty acid pathways (PUFA synthase or PKS), highly active under low dissolved oxygen (Matsuda et al., 2012; Metz et al., 2001). Studies on transcriptome and gene expression analysis of Schizochytrium sp. under different oxygen supply conditions have shown that high oxygen supply is used in NADPH and acetyl-CoA production for cell growth, rather than for DHA production (Bi et al., 2018).

Consequently, high $\mathrm{k}_{\mathrm{L}}$ a is required for growth, while DHA production does not require a very high oxygen supply (Chang et al., 2014). 
433

434

435

436

437

438

439

440

441

442

\section{CONCLUSIONS}

444

445

446

447

448

449

450

451

452

453

454

455

456

457

458

459

460

461

Therefore, ILAB can be used as an alternative to the STB bioreactor, with production performance similar to the standard rotary shaker. However, STB is still the most suitable bioreactor for thraustochytrids if biomass yield is the major priority, followed by production of intracellular products (Hoseinkhani et al., 2019). The simplified and low-cost ILAB design used in this study shows favorable production from Aurantiochytrium with 23.41-36.05 g/L biomass and 36.93-40.29\% DHA in total fatty acids. This production yield is comparable to previous studies, which reported ranges of 13-59.2 g/L biomass (72 and $125 \mathrm{~h})$ and 31.09-52.3\% TFA (72 and 36 h) (Table 3) (Yaguchi et al., 1997; Rosa et al., 2010; Ethier et al., 2011; Hong et al., 2013; Lee Chang et al., 2013).

Three designs of low-cost bioreactors, stirred tank (STB), bubble (BB) and air-lift (ILAB) were evaluated for cultivation of Aurantiochytrium limacinum and DHA production, in combination with optimized sparger (eight super-fine bubble air stones) and aeration rate (between 1.5-2 vvm). All reactors are capable of thraustochytrid cultivation, with growth and yield comparable to a 200-rpm rotary shaking flask. Each bioreactor type has unique advantages. STB had the highest $\mathrm{k}_{\mathrm{L}}$ a values $\left(155.92 \pm 18.52 \mathrm{~h}^{-1}\right)$, producing the highest biomass $(43.05 \pm 0.35 \mathrm{~g} / \mathrm{L})$. However, agitation by the impeller causes shear stress damage to the cells, and may affect fatty acid production. BB is simple in design, easiest to build, and lowest cost. However, thraustochytrid cultivation in $\mathrm{BB}$ requires a high airflow rate in order to avoid cell sedimentation during cultivation. ILAB provided moderate cell density $(37.60 \pm 3.82 \mathrm{~g} / \mathrm{L})$ but the highest amount of fatty acids (199.02 $\pm 0.41 \mathrm{mg} / \mathrm{g} \mathrm{DW}, 35.36 \pm 2.51 \%$ TFA). With ILAB, the uniform flow pattern through the riser and downcomer in the bioreactor allows homogeneous mixing, and hence is appropriate for oleaginous cell growth. For further study, other equipment designs should be investigated that could reduce cell sedimentation, as found in BB and ILAB bioreactors. Moreover, the shape of ILAB might be redesigned, in order to accommodate the fine bubbles formed and higher air flow rate, which induces high amounts of foaming.

\section{ACKNOWLEDGEMENTS}


462 The authors are grateful for the technical assistance from the staff of the Major of Environmental 463 Science and Department of Aquatic Science, Faculty of Science, Burapha University, Chonburi, 464 Thailand.

465

466

REFERECES

467

468

469

470

471

472

473

474

475

476

477

478

479

480

481

482

483

484

485

486

487

488

489

490

491

Asztalos IB, Gleason JA, Sever S, Gedik R, Asztalos BF, Horvath KV, Dansinger ML, Lamon-Fava S, Schaefer EJ. 2016. Effects of eicosapentaenoic acid and docosahexaenoic acid on cardiovascular disease risk factors: a randomized clinical trial. Metabolism 65:1636-1645 DOI 10.1016/j.metabol.2016.07.010.

Barigou M, Greaves M. 1996. Gas holdup and interfacial area distributions in a mechanically agitated gas-liquid contactor. Transactions of Institutions of Chemical Engineers 74:397405.

Bi ZQ, Ren LJ, Hu XC, Sun XM, Zhu SY, Ji XJ, Huang H. 2018. Transcriptome and gene expression analysis of docosahexaenoic acid producer Schizochytrium sp. under different oxygen supply conditions. Biotechnology for Biofuels 11:249 DOI 10.1186/s13068-0181250-5.

Bouaifi M, Hebrard G, Bastoul D, Roustan M. 2001. A comparative study of gas hold-up, bubble size, interfacial area and mass transfer coefficients in stirred gas-liquid reactors and bubble columns. Chemical Engineering and Processing 40: 97-111 DOI 10.1016/S0255-2701(00)00129-X.

Cerri MO, Badino AC. 2010. Oxygen transfer in three scales of concentric tube airlift bioreactors. Biochemical Engineering Journal 51:40-47 DOI 10.1016/j.bej.2010.04.013.

Chang G, Gao N, Tian G, Wu Q, Chang M, Wang X. 2013. Improvement of docosahexaenoic acid production on glycerol by Schizochytrium sp. S31 with constantly high oxygen transfer coefficient. Bioresource Technology 142:400-406 DOI 10.1016/j.synbio. 2018.04.001.

Chang G, Wu J, Jiang C, Tian G, Wu Q, Chang M, Wang X. 2014. The relationship of oxygen uptake rate and $\mathrm{k}_{\mathrm{L}}$ a with rheological properties in high cell density cultivation of docosahexaenoic acid by Schizochytrium sp. S31. Bioresource Technology 152:234240 DOI 10.1016/j.biortech.2013.11.002.

Peer) reviewing PDF | (2020:10:54555:1:0:NEW 14 Mar 2021) 
492

493

494

495

496

497

498

499

500

501

502

503

504

505

506

507

508

509

510

511

512

513

514

515

516

517

518

519

520

De Wilde D, Dreher T, Zahnow C, Husemann U, Greller G, Adams T, Fenge C. 2014. Superior scalability of single-use bioreactors. In: Montgomery SA, ed. Innovations in Cell Culture. New York: Life Sciences, 14-19.

Ethier S, Woisard K, Vaughan D, Wen Z. 2011. Continuous culture of the microalgae Schizochytrium limacinum on biodiesel-derived crude glycerol for producing docosahexaenoic acid. Bioresource Technology 102:88-93 DOI 10.1016/j. biortech.2010.05.021.

Fontana RC, Polidoro TA, da Silveira MM. 2009. Comparison of stirred tank and airlift bioreactors in the production of polygalacturonases by Aspergillus oryzae. Bioresource Technology 100:4493-4498 DOI 10.1016/j.biortech.2008.11.062.

Garcia-Ochoa F, Gomez E. 2009. Bioreactor scale-up and oxygen transfer rate in microbial processes: An overview. Biotechnology Advances 27:153-176 DOI 10.1016/j. biotechadv.2008.10.006.

Garcia-Ochoa F, Gomez E, Santos VE, Merchuk JC. 2010. Oxygen uptake rate in microbial processes: An overview. Biochemical Engineering Journal 49:289-307 DOI 10.1016/ j.bej.2010.01.011.

Hong WK, Yu A, Oh BR, Park JM, Kim CH, Sohn JH, Kondo A, Seo JW. 2013. Largescale production of microalgal lipids containing high levels of docosahexaenoic acid upon fermentation of Aurantiochytrium sp. KRS101. Food and Nutrition Sciences 4:1-5 DOI 10.4236/fns.2013.49A1001.

Horrocks LA, Yeo YK. 1999. Health benefits of docosahexaenoic acid (DHA). Pharmacological Research 40:211-225 DOI 10.1006/phrs.1999.0495.

Hoseinkhani N, Jalili H, Ansari S, Amrane A. 2019. Impact of bubble size on docosahexaenoic acid production by Crypthecodinium cohnii in bubble column bioreactor. Biomass Conversion and Biorefinery DOI 10.1007/s13399-019-00510-5.

Humbrid D, Davis R, McMillan JD. 2017. Aeration costs in stirred-tank and bubble column bioreactors. Biochemical Engineering Journal 127:161-166 DOI 10.1016/j.bej. 2017.08.006.

Jakobsen AN, Aasen IM, Josefsen KD, Strom AR. 2008. Accumulation of docosahexaenoic 
521

522

523

524

525

526

527

528

529

530

531

532

533

534

535

536

537

538

539

540

541

542

543

544

545

546

547

548

549

550

551

acid-rich lipid in thraustochytrid Aurantiochytrium sp. strain T66: effects of N and P starvation and $\mathrm{O}_{2}$ limitation. Applied Microbiology and Biotechnology 80:297-306 DOI $10.1007 / \mathrm{s} 00253-008-1537-8$.

Jaritkhuan S, Suanjit S. 2018. Species diversity and polyunsaturated fatty acid content of thraustochytrids from fallen mangrove leaves in Chon Buri province, Thailand. Agriculture and Natural Resources 52:24-32 DOI 10.1016/j.anres.2018.05.002.

Joshi JB, Pandit AB, Sharma MM. 1982. Mechanically agitated gas-liquid reactors. Chemical Engineering Science 37:813-844 DOI 10.1016/0009-2509(82)80171-1.

Ju JH, Oh BR, Ko DJ, Heo SY, Lee JJ, Kim YM, Yang KS, Seo JW, Hong WK, Kim CH. 2019. Boosting productivity of heterotrophic microalgae by efficient control of the oxygen transfer coefficient using a microbubble sparger. Algal Research 41:101474 DOI 10.1016/j.algal.2019.101474.

Kantarci N, Borak F, Ulgen KO. 2005. Bubble column reactors. Process Biochemistry 40:2263-2283 DOI 10.1016/j.procbio.2004.10.004.

Karimi A, Golbabaei F, Mehrnia MR, Neghab M, Mohammad K, Nikpey A, Pourmand MR. 2013. Oxygen mass transfer in a stirred tank bioreactor using different impeller configurations for environmental purposes. Iranian Journal of Environmental Health Sciences \& Engineering 10:6 DOI 10.1186/1735-2746-10-6.

Kato Y, Tada Y, Iwanaga E, Nagatsu Y, Iwata S, Lee YS, Koh ST. 2005. Effects of liquid film formed on flask surface on oxygen transfer rate in shaking flask and development of baffled shaking vessel by optical method based on sulfite oxidation. Journal of chemical engineering of Japan 38:873-877 DOI 10.1252/jcej.38.873.

Kawase Y, Moo-Young M. 1990. Mathematical models for design of bioreactors: applications of: Kolmogoroff's theory of isotropic turbulence. The Chemical Engineering Journal 43:B19-B41 DOI 10.1016/0300-9467(90)80048-H.

Kawase Y, Halard B, Moo-Young M. 1992. Liquid-phase mass transfer coefficients in bioreactors. Biotechnology and Bioengineering 39:1133-1140 DOI 10.1002/bit. 260391109.

Kim K, Kim EJ, Ryu BG, Park S, Choi YE, Yang JW. 2013. A novel fed-batch process based on the biology of Aurantiochytrium sp. KRS101 for the production of biodiesel and docosahexaenoic acid. Bioresource Technology 135:269-274 DOI 10.1016/j. 
552

553

554

555

556

557

558

559

560

561

562

563

564

565

566

567

568

569

570

571

572

573

574

575

576

577

578

579

580

581

582

biortech.2012.10.139.

Kim SW, Kang SW, Lee JS. 1997. Cellulase and xylanase production by Aspergillus niger KKS in various bioreactors. Bioresource Technology 59:63-67 DOI 10.1016/S09608524(96)00127-7.

Kumar RN, Vinod AV. 2014. Oxygen mass transfer in bubble column bioreactor. Periodica Polytechnica Chemical Engineering 58:21-30 DOI 10.3311/PPch.7122.

Lee Chang KJ, Dumsday G, Nichols PD, Dunstan GA, Blackburn SI, Koutoulis A. 2013. High cell density cultivation of a novel Aurantiochytrium sp. strain TC 20 in a fed-batch system using glycerol to produce feedstock for biodiesel and omega-3 oils. Applied Microbiology and Biotechnology 97:6907-6918 DOI 10.1007/s00253-013-4965-z.

Marchan LF, Chang KJL, Nichols PD, Mitchell WJ, Polglase JL, Gutierrez T. 2018. Taxonomy, ecology and biotechnological applications of thraustochytrids: A review. Biotechnology Advances 36:26-46 DOI 10.1016/j.biotechadv.2017.09.003.

Matsuda T, Sakaguchi K, Hamaguchi R, Kobayashi T, Abe E, Hama, Y, Hayashi M, Honda D, Okita Y, Sugimoto S, Okino N, Ito M. 2012. Analysis of $\Delta 12$-fatty acid desaturase function revealed that two distinct pathways are active for the synthesis of PUFAs in T. aureum ATCC 34304. Journal of Lipid Research 53:1210-1222 DOI 10.1194/j1r.M024935.

Metz JG, Roessler P, Facciotti D, Levering C, Dittrich F, Lassner M, Valentine R, Lardizabal K, Domergue F, Yamada A, Yazawa K, Knauf V, Browse J. 2001. Production of polyunsaturated fatty acids by polyketide synthases in both prokaryotes and eukaryotes. Science 293:290-293 DOI 10.1126/science.1059593.

Michelin M, Mota AMO, Polizeli MLTM, Silva DP, Vicente AA, Teixeira JA. 2013. Influence of volumetric oxygen transfer coefficient $\left(\mathrm{k}_{\mathrm{L}} \mathrm{a}\right)$ on xylanases batch production by Aspergillus niger van Tieghem in stirred tank and internal-loop airlift bioreactors. Biochemical Engineering Journal 80:19-26 DOI 10.1016/j.bej.2013.09.002.

Miller GL. 1959. Use of dinitrosalicylic acid reagent for determination of reducing sugar. Analytical Chemistry 31:426-428 DOI 10.1021/ac60147a030.

Mohagheghian S, Elbing BR. 2018. Characterization of bubble size distributions within a bubble column. Fluids 3:13 DOI 10.3390/fluids3010013.

Morita E, Kumon Y, Nakahara T, Kagiwada S, Noguchi T. 2006. Docosahexaenoic acid 
583

584

585

586

587

588

589

590

591

592

593

594

595

596

597

598

599

600

601

602

603

604

605

606

607

608

609

610

611

612

production and lipid body formation in Schizochytrium limacinum SR21. Marine Biotechnology 8:319-327 DOI 10.1007/s10126-005-5060-y.

Osendarp SJM. 2011. The role of omega-3 fatty acids in child development. Journees Chevreul 2011 Lipids and Brain 18:307-313 DOI 10.1684/ocl.2011.0417.

Özcan E, Sargın S, Göksungur Y. 2014. Comparison of pullulan production performances of air-lift and bubble column bioreactors and optimization of process parameters in air-lift bioreactor. Biochemical Engineering Journal 92:9-15 DOI 10.1016/j.bej.2014.05.017.

Puskeiler R, Weuster-Botz D. 2005. Combined sulfite method for the measurement of the oxygen transfer coefficient $\mathrm{k}_{\mathrm{L}} a$ in bioreactors. Journal of Biotechnology 120:430-438 DOI 10.1016/j.jbiotec.2005.06.016.

Qu L, Ji XJ, Ren LJ, Nie ZK, Feng Y, Wu WJ, Ouyang PK, Huang H. 2010. Enhancement of docosahexaenoic acid production by Schizochytrium sp. using a two-stage oxygen supply control strategy based on oxygen transfer coefficient. Letters in Applied Microbiology 52:22-27 DOI 10.1111/j.1472-765X.2010.02960.x.

Reyes-Jara A, Cordero N, Aguirre J, Troncoso M, Figueroa G. 2016. Antibacterial effect of copper on microorganisms isolated from bovine mastitis. Frontiers in Microbiology 7:626 DOI 10.3389/fmicb.2016.00626.

Rosa SM, Soria MA, Vélez CG, Galvagno MA. 2010. Improvement of a two-stage fermentation process for docosahexaenoic acid production by Aurantiochytrium limacinum SR21 applying statistical experimental designs and data analysis. Bioresource Technology 101:2367-2374 DOI 10.1016/j.biortech.2009.11.056.

Ryosuke N, Takeshi, N. 2015. Diversity and Ecology of Thraustochytrid Protists in the Marine Environment. Marine Protists. 331-346 DOI 10.1007/978-4-431-55130_13.

Saravanan P, Pakshirajan K, Saha P. 2008. Biodegradation of phenol and $m$-cresol in a batch and fed batch operated internal loop airlift bioreactor by indigenous mixed microbial culture predominantly Pseudomonas sp. Bioresource Technology 99:85538558 DOI 10.1016/j.biortech.2008.04.003.

Scragg AH. 1991. Bioreactors in biotechnology: A practical approach. New York: Ellis Horwood.

Shimizu S, Kawashima H, Shinmen Y, Akimoto K, Yamada H. 1988. Production of 
613

614

615

616

617

618

619

620

621

622

623

624

625

626

627

628

629

630

631

632

633

634

635

636

637

638

639

640

641

eicosapentaenoic acid by Mortierella fungi. Journal of the American Oil Chemists 'Society 65:1455-1459 DOI 10.1007/BF02898307.

Sinha RP, Dautz M, Hader D-P. 2001. A simple and efficient method for the quantitative analysis of thymine dimers in cyanobacteria, phytoplankton and macroalgae. Acta Protozoologica 40:187-195.

Stanbury PF, Whitaker A, Hall SJ. 1995. Media for industrial fermentations. Principles of Fermentation Technology. Oxford: Pergamon Press.

Sundaramurthy S, Srivastava VC, Mishra I. 2011. Variables affecting the oxygen mass transfer in bioreactors. Comprehensive Biotechnology 2:947-956 DOI 10.1016/B978-008-088504-9.00409-8.

Unagul P, Suetrong S, Preedanon S, Klaysuban A, Gundool W, Suriyachadkun C, Sakayaroj J. 2017. Isolation, fatty acid profiles and cryopreservation of marine thraustochytrids from mangrove habitats in Thailand. Botanica Marina 60:363-379 DOI 10.1515/bot-2016-0111.

Wang C, Lan CQ. 2018. Effects of shear stress on microalgae - A review. Biotechnology Advances 36:986-1002 DOI 10.1016/j.biotechadv.2018.03.001.

Wase DAJ, McManamey WJ, Raymahasay S, Vaid AK. 1985. Comparisons between cellulase production by Aspergillus fumigatus in agitated vessels and in an air-lift fermentor. Biotechnology and Bioengineering 27:1166-1172 DOI 10.1002/ bit. 260270811.

Wegrich RH, Shurter RA. 1953. Development of a typical aerobic fermentation. Journal of Industrial and Engineering Chemistry 45:1153-1160 DOI 10.1021/ie50521a070.

Yaguchi T, Tanaka S, Yokochi T, Nakahara T, Higashihara T. 1997. Production of high yields of docosahexaenoic acid by Schizochytrium sp. strain SR21. Journal of the American Oil Chemists' Society 74:1431-1434 DOI 10.1007/s11746-997-0249-z.

Yen HW, Liu YX. 2014. Application of airlift bioreactor for the cultivation of aerobic oleaginous yeast Rhodotorula glutinis with different aeration rates. Journal of Bioscience and Bioengineering 118:195-198 DOI 10.1016/j.jbiosc.2014.01.002.

Peer) reviewing PDF | (2020:10:54555:1:0:NEW 14 Mar 2021) 
Figure 1

Experimental design. 


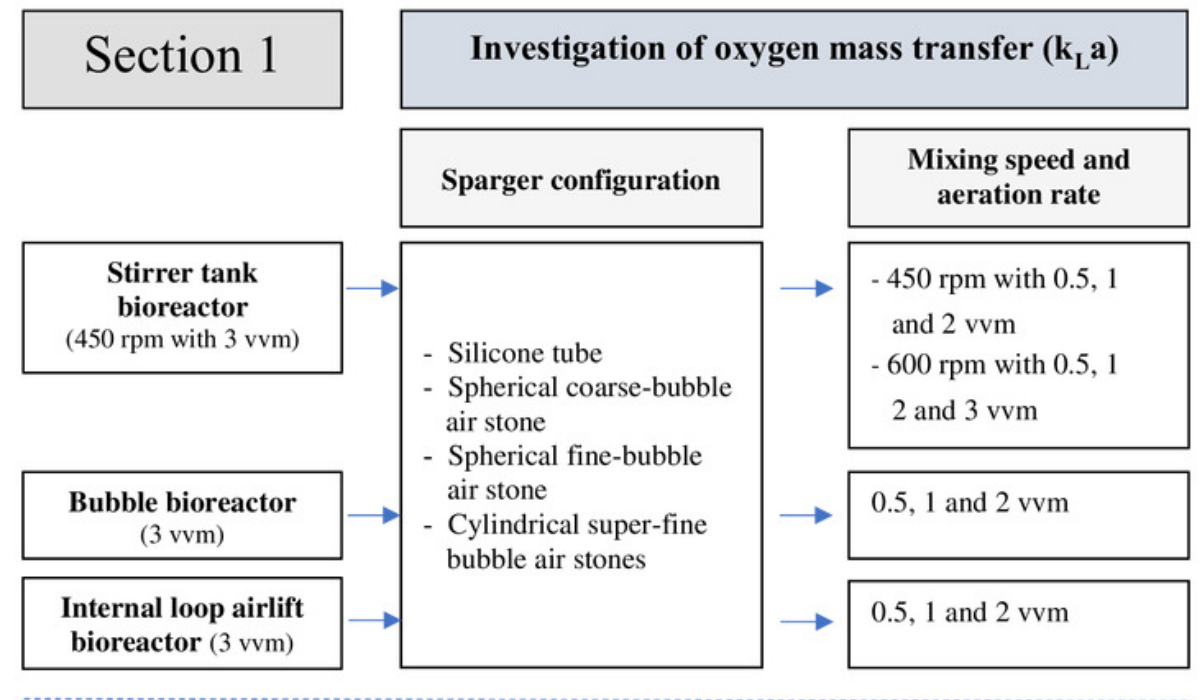

\section{Section 2}

Using best conditions from section 1
Test the efficiency of the developed bioreactors

Culturing with adding anti-foam

Culturing without adding anti-foam

Comparison of biomass and DHA with standard incubator shaker conditions 


\section{Figure 2}

Photographs and configurations of three bioreactors with spargers.

(A) Stirred tank bioreactor (STB), (B) Bubble bioreactor (BB), (C) Internal loop airlift bioreactor (ILAB).
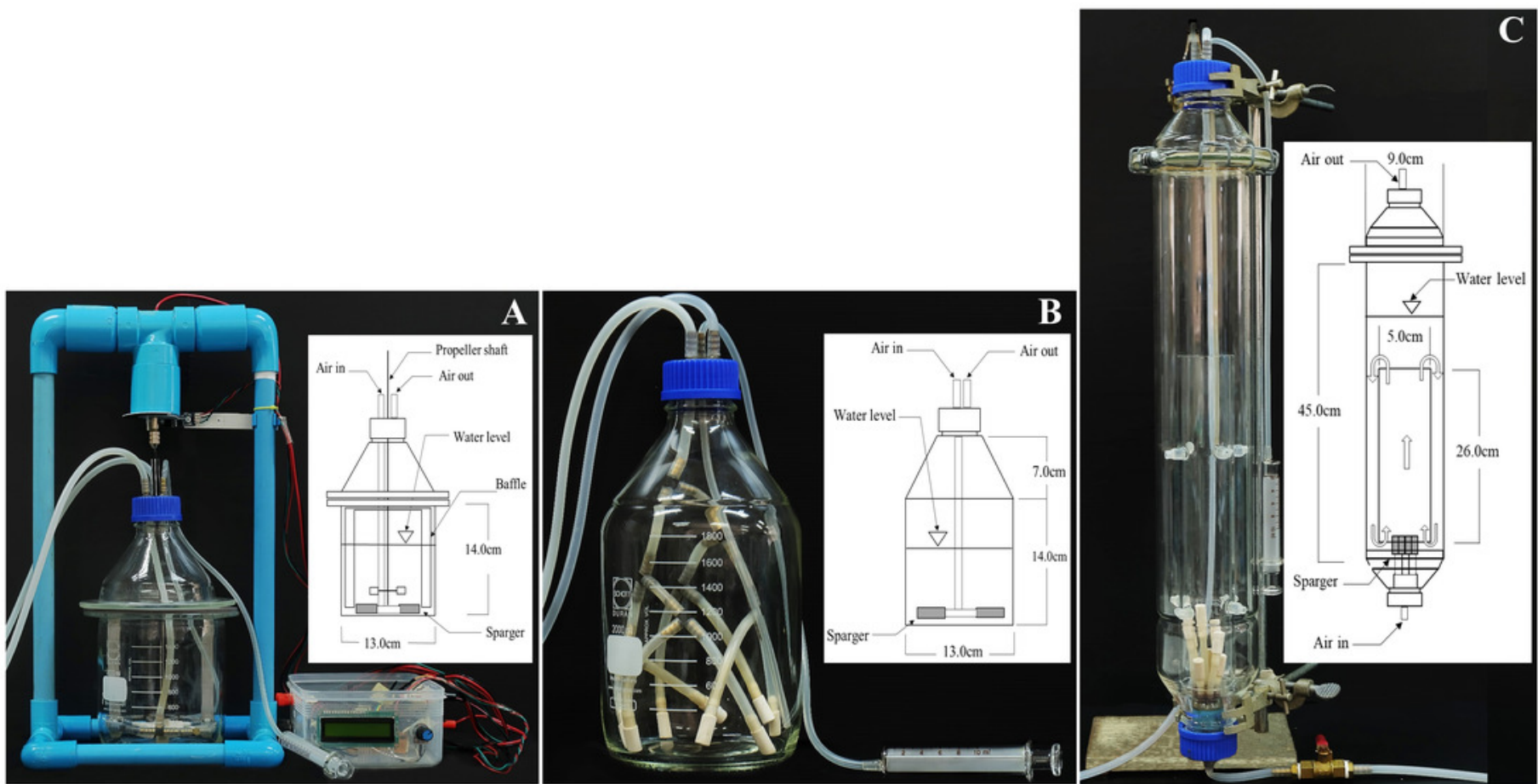
Figure 3

Bioreactor aeration system.

Air out from the air compressor passes through two filters and UV light faces all bioreactors; aeration rate is controlled by the rotameter.

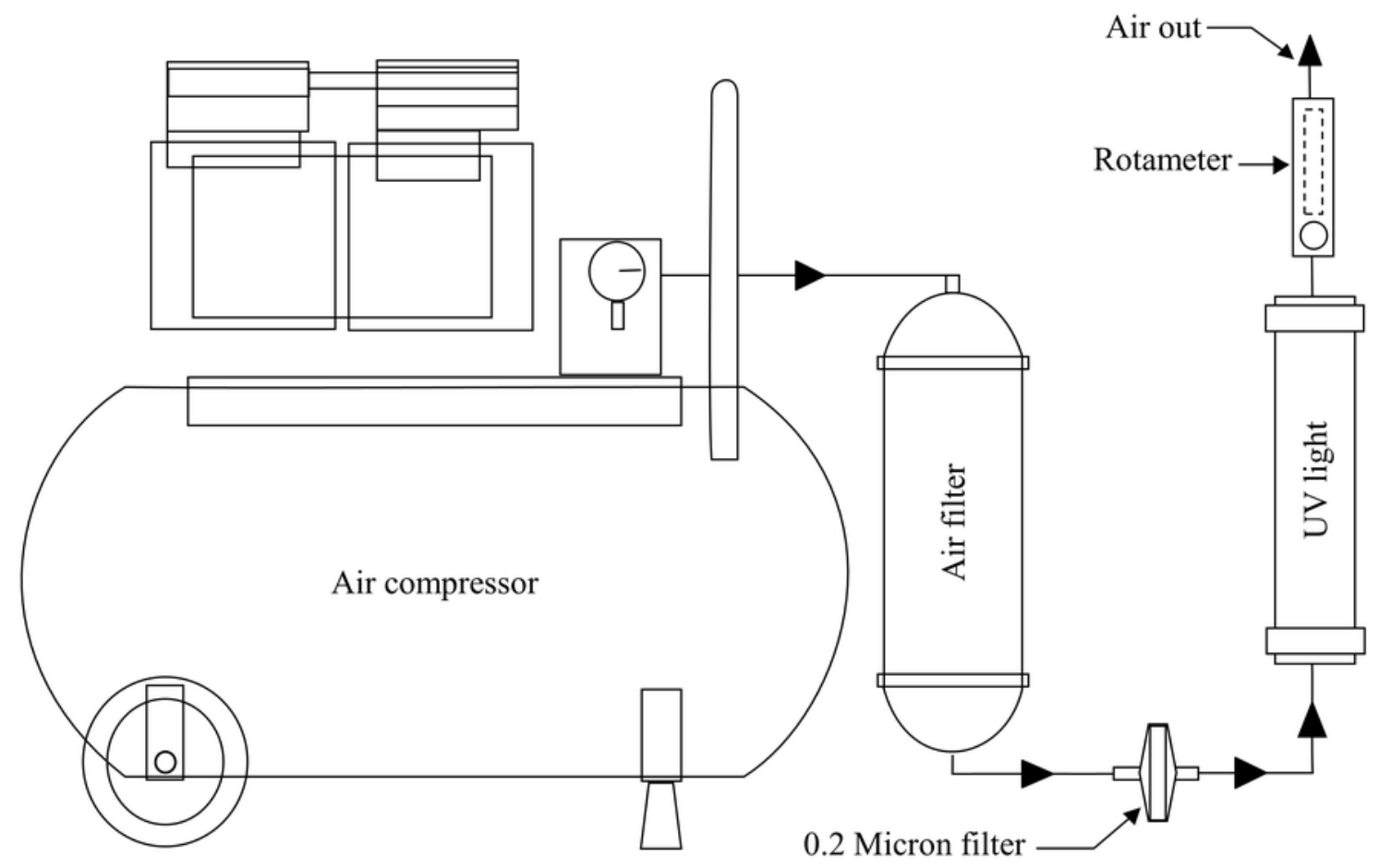




\section{Figure 4}

Sparger types.

(A) silicone tube, (B) spherical coarse-bubble air stone, (C) spherical fine-bubble air stone, (D) cylindrical super-fine bubble air stone.
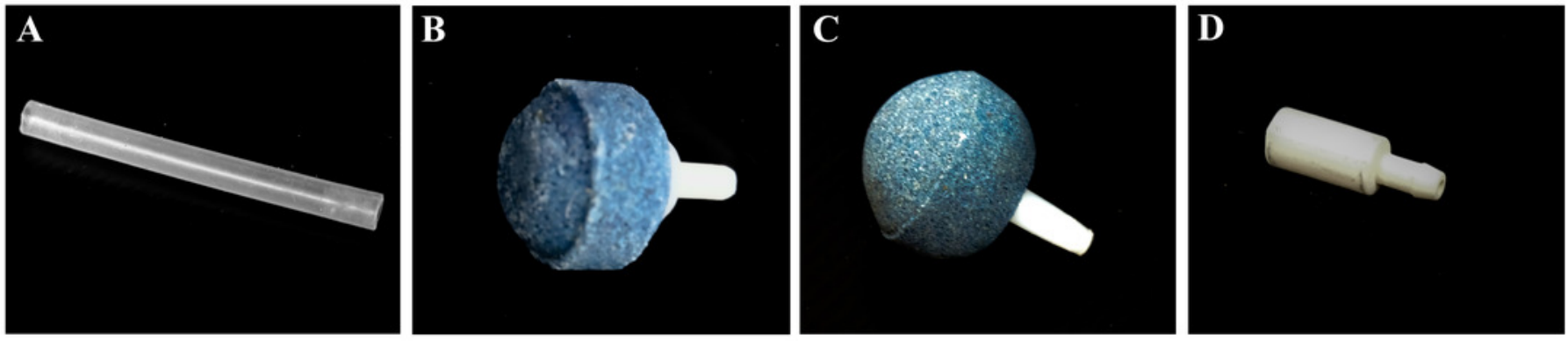
Figure 5

$\mathrm{k}_{\mathrm{L}} \mathrm{a}$ values in three bioreactors using different sparger configurations.

All sparger types were tested, using aeration rate of $3 \mathrm{vvm}$ in bubble, internal loop airlift and stirred tank bioreactor, with an agitation speed of $450 \mathrm{rpm}$. 


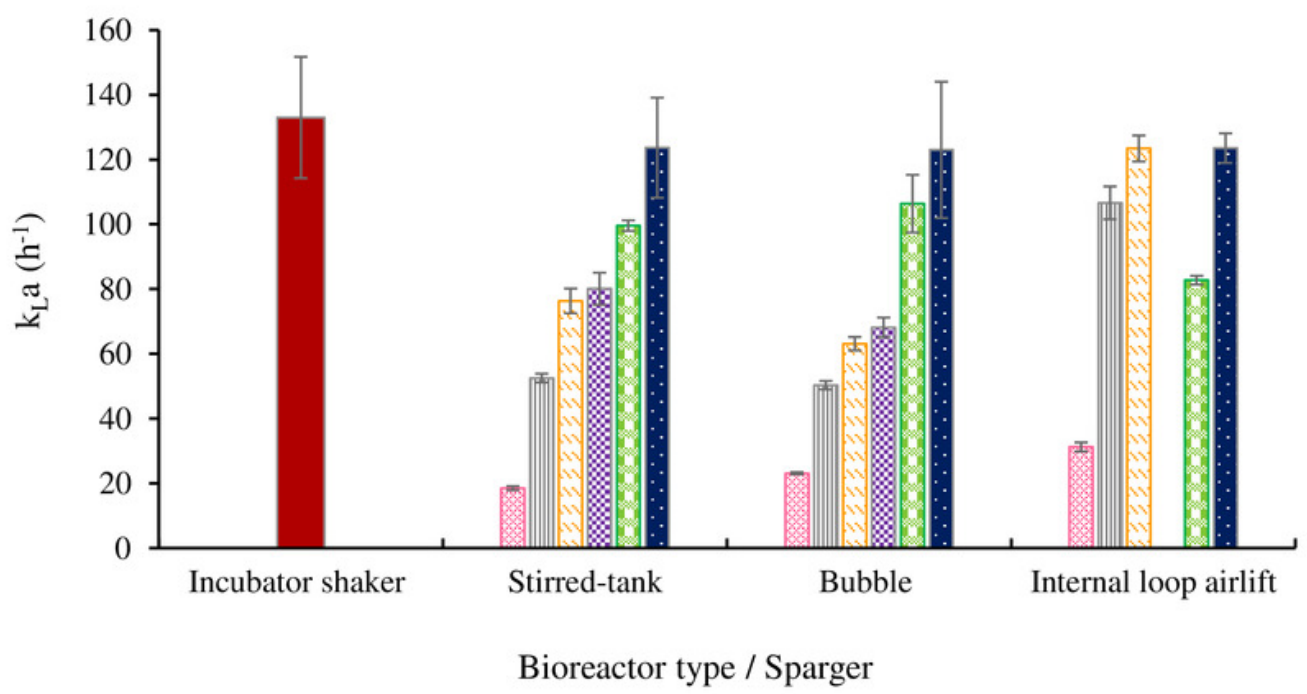

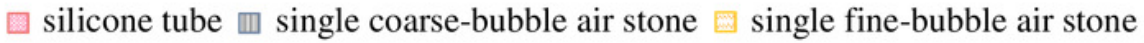
$\square$ four fine-bubble air stones $⿴ 囗 \mathrm{~g}$ four cylindrical super-fine bubble air stones eight cylindrical super-fine bubble air stones 
Figure 6

Biomass and total sugar during $120 \mathrm{~h}$ and168 $\mathrm{h}$ fermentation of $A$. limacinum BUCHAXM 122 in different bioreactors with constant initial sugar concentration $(60 \mathrm{~g} / \mathrm{L})$.

(A, B) Shaker at $200 \mathrm{rpm}$; (C, D) Stirred tank bioreactor at $2 \mathrm{vvm}$ and $0.1 \mathrm{vvm;}(\mathrm{E}, \mathrm{F})$ Bubble bioreactor at $2 \mathrm{vvm}$ and $0.1 \mathrm{vvm} ;(\mathrm{G}, \mathrm{H})$ Internal loop airlift bioreactor at $1.5 \mathrm{vvm}$ and 0.1 vvm. 

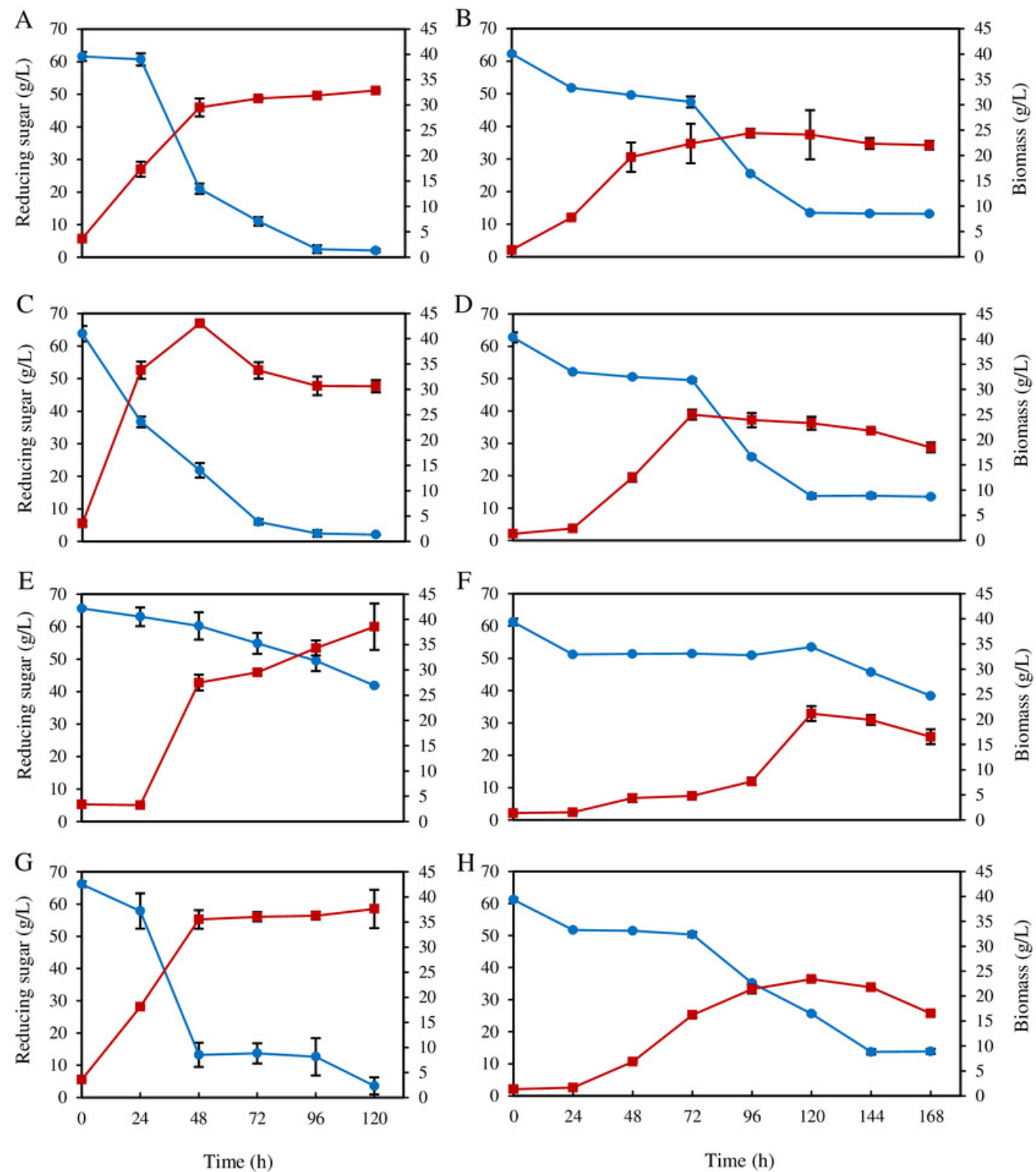

- Reducing sugar - Biomass 


\section{Figure 7}

DHA (mg/g DW) (A) and fatty acid (\% TFA) (B) production by A. limacinum BUCHAXM 122 during $120 \mathrm{~h}$ in different bioreactor types.

Aeration provided at $2 \mathrm{vvm}$ for bubble and stirred tank bioreactors with agitation speed at $600 \mathrm{rpm}$ and $1.5 \mathrm{vvm}$ for internal loop airlift bioreactor. 

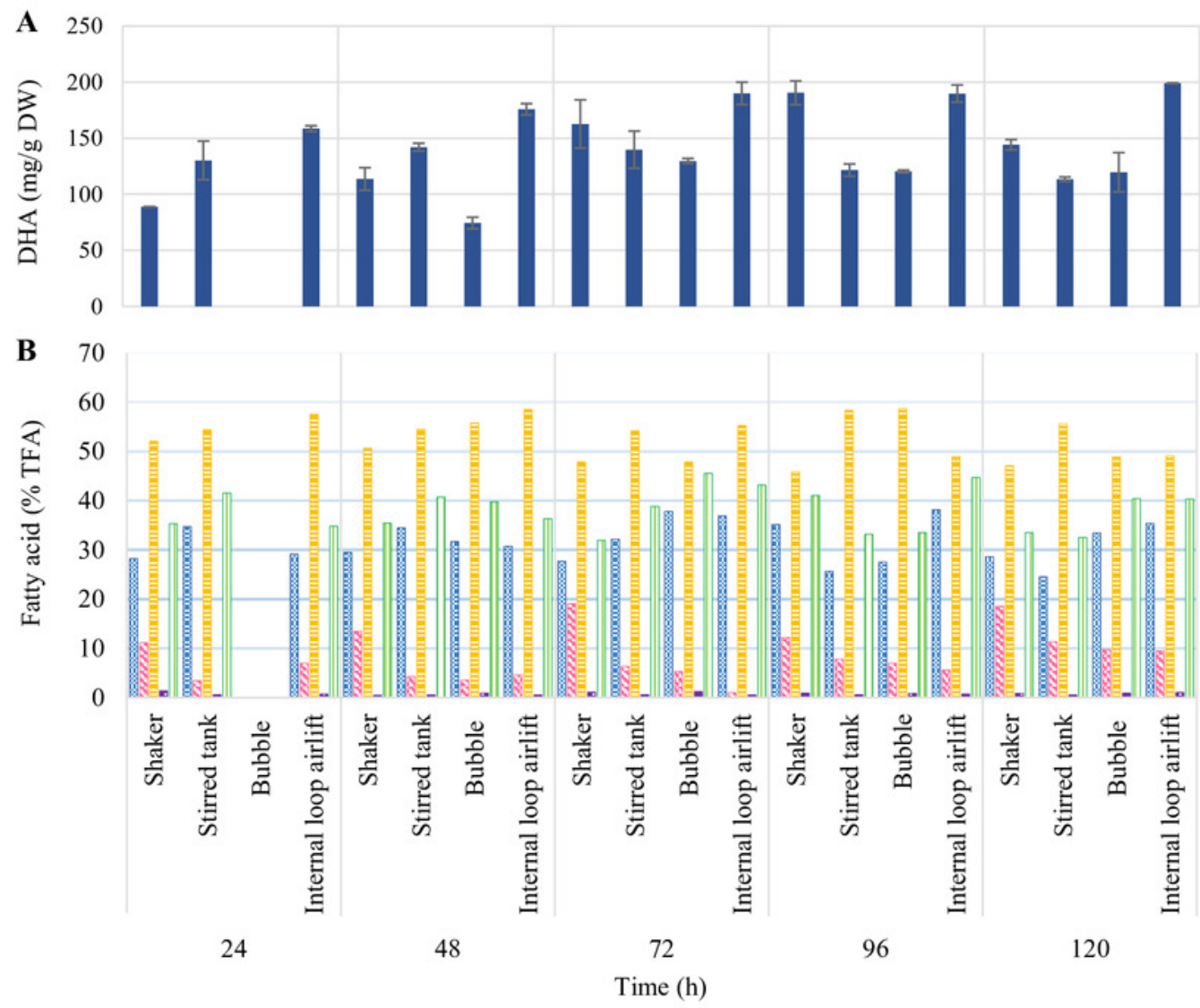

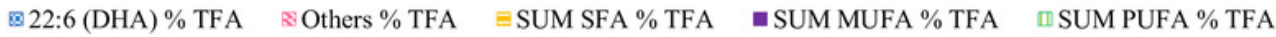


Figure 8

Exponential relationship between aeration rate and $\mathrm{k}_{\mathrm{L}} \mathrm{a}$ in different bioreactors and shaker.

The $k_{\llcorner} a$ values at $0.5,1,2$ and $3 \mathrm{vvm}$ in bubble, internal loop airlift and stirred tank bioreactors with agitation speeds of $600 \mathrm{rpm}$ and $200 \mathrm{rpm}$ in shaker. 


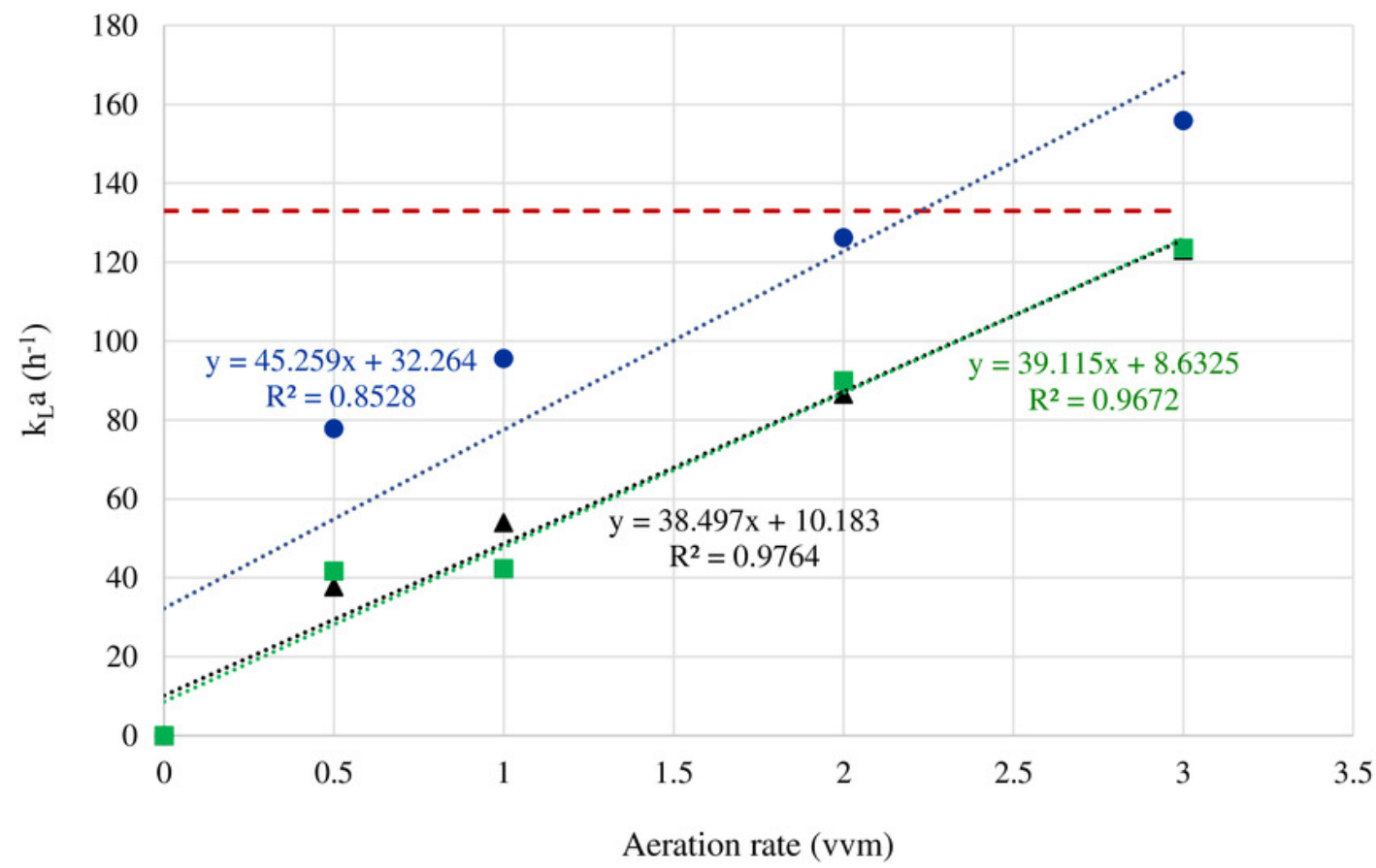

- - - Shaker $\bullet$ Stirrer tank $\Delta$ Bubble $\square$ Internal loop airlift-type 


\section{Table 1 (on next page)}

$\mathrm{k}_{\mathrm{L}} \mathrm{a}$ values for bioreactors at different agitation speeds and aeration rates. 
1

\begin{tabular}{ccccc}
\hline \multirow{2}{*}{$\begin{array}{c}\text { Aeration } \\
\text { Rate (vvm) }\end{array}$} & \multicolumn{3}{c}{$\mathbf{k}_{\mathbf{L}} \mathbf{a}\left(\mathbf{h}^{\mathbf{- 1}}\right)$} \\
\cline { 2 - 4 } & \multicolumn{2}{c}{ Stirred } & Bubble & Internal loop \\
\cline { 2 - 4 } & $51.03 \pm 2.72^{\mathrm{a}}$ & $77.18 \pm 5.10^{\mathrm{b}}$ & $37.70 \pm 1.45^{\mathrm{a}}$ & airlift \\
\hline 0.5 & $82.38 \pm 3.38^{\mathrm{b}}$ & $95.57 \pm 4.86^{\mathrm{c}}$ & $53.96 \pm 1.13^{\mathrm{b}}$ & $42.33 \pm 2.16^{\mathrm{a}}$ \\
1.0 & $129.71 \pm 5.03^{\mathrm{d}}$ & $126.21 \pm 7.65^{\mathrm{d}}$ & $86.50 \pm 2.93^{\mathrm{c}}$ & $89.87 \pm 3.58^{\mathrm{b}}$ \\
2.0 & $123.66 \pm 15.47^{\mathrm{d}}$ & $155.92 \pm 18.52^{\mathrm{e}}$ & $122.99 \pm 21.04^{\mathrm{d}}$ & $123.53 \pm 4.57^{\mathrm{c}}$
\end{tabular}

2 Mean for each bioreactor type with different superscript letters are significantly different at $3 \mathrm{p}<0.05$. 


\section{Table 2 (on next page)}

DHA production at $168 \mathrm{~h}$ in different bioreactor types, provided with aeration at 0.1 vvm. 
1

\begin{tabular}{llcccc}
\hline \multirow{2}{*}{ Fatty acid } & \multicolumn{2}{c}{ Shaker } & Stirred tank & Bubble & $\begin{array}{c}\text { Internal loop } \\
\text { airlift }\end{array}$ \\
\hline $22: 6(\mathrm{DHA})$ & $\mathrm{mg} / \mathrm{g} \mathrm{DW}$ & $237.78 \pm 35.04^{\mathrm{a}}$ & $217.08 \pm 6.85^{\mathrm{a}}$ & $75.53 \pm 15.79^{\mathrm{b}}$ & $250.48 \pm 18.51^{\mathrm{a}}$ \\
\cline { 2 - 6 } & $\%$ TFA & $39.05 \pm 3.44^{\mathrm{a}}$ & $34.04 \pm 0.79^{\mathrm{a}}$ & $19.84 \pm 2.86^{\mathrm{b}}$ & $40.20 \pm 6.09^{\mathrm{a}}$ \\
\hline Others & $\%$ TFA & $2.34 \pm 0.10^{\mathrm{a}}$ & $4.38 \pm 4.12^{\mathrm{a}}$ & $2.89 \pm 0.22^{\mathrm{a}}$ & $11.08 \pm 13.87^{\mathrm{a}}$ \\
\hline SUM SFA & $\%$ TFA & $49.85 \pm 3.61^{\mathrm{a}}$ & $52.64 \pm 4.58^{\mathrm{ab}}$ & $68.69 \pm 0.83^{\mathrm{b}}$ & $42.82 \pm 10.47^{\mathrm{a}}$ \\
\hline SUM MUFA & $\%$ TFA & $1.13 \pm 0.05^{\mathrm{a}}$ & $1.25 \pm 0.01^{\mathrm{a}}$ & $3.57 \pm 4.38^{\mathrm{a}}$ & $1.57 \pm 0.37^{\mathrm{a}}$ \\
\hline SUM PUFA & $\%$ TFA & $46.68 \pm 3.66^{\mathrm{a}}$ & $41.72 \pm 0.47^{\mathrm{a}}$ & $24.86 \pm 3.33^{\mathrm{b}}$ & $44.52 \pm 3.03^{\mathrm{a}}$
\end{tabular}

2 Means with different superscript letters (in rows) are significantly different $(\mathrm{p}<0.05)$;

$3 \mathrm{FA}=$ saturated fatty acids, MUFA $=$ monounsaturated fatty acids, PUFA = polyunsaturated fatty 4 acids. 


\section{Table 3 (on next page)}

Biomass and DHA yields for Aurantiochytrium sp. grown with different bioreactor types and culture media. 


\begin{tabular}{|c|c|c|c|c|c|c|}
\hline Bioreactor type & Strain & $\begin{array}{c}\text { Carbon and } \\
\text { nitrogen source }\end{array}$ & $\begin{array}{l}\text { Fermentation volume (L) } \\
\text { and Conditions }\end{array}$ & Biomass (g/L) & DHA (\% TFA) & Reference \\
\hline \multirow{15}{*}{ Stirrer tank } & A. limacinum $\mathrm{SR} 21^{\mathrm{a}}$ & Glucose & $3 \mathrm{~L}$ (Fed batch) & $21.9-59.2$ & $33.3-38.6$ & Yaguchi et al. (1997) \\
\hline & & $\left(\mathrm{NH}_{4}\right) 2 \mathrm{SO}_{4}$ & $300 \mathrm{rpm}$ & $(62-125 \mathrm{~h})$ & (92 h) & \\
\hline & & Corn steep liquor & & & & \\
\hline & A. limacinum $\mathrm{SR} 21^{\mathrm{a}}$ & Glucose & $3.5 \mathrm{~L}$ & 51.95 & & Rosa et al. 2010 \\
\hline & & Corn steep liquor & $300-500 \mathrm{rpm}, 1.71 \mathrm{vvm}$, & (72 h) & - & \\
\hline & & Ammonium acetate & $28^{\circ} \mathrm{C}$ & & & \\
\hline & A. limacinum $\mathrm{SR} 21^{\mathrm{a}}$ & Crude glycerol & 4.5 L (Continuous) & 13 & 31.09 & Ethier et al. (2011) \\
\hline & (ATCC MYA-1381) & YP & $0.1 \mathrm{vvm}$ & ( after $72 \mathrm{~h})$ & (after $72 \mathrm{~h}$ ) & \\
\hline & Aurantiochytrium sp. & GY & $3,000 \mathrm{~L}$ & 30.5 & 39.5 & Hong et al. (2013) \\
\hline & KRS101 & & & (after $48 \mathrm{~h}$ ) & (after $48 \mathrm{~h}$ ) & \\
\hline & Aurantiochytrium sp. & GYP & $1.6 \mathrm{~L}$ (Fed batch) & 56.6 & 43.2 & Lee Chang et al. \\
\hline & TC20 & & $300-1,150 \mathrm{rpm}, 0.3-1.5 \mathrm{vvm}$ & $(69 \mathrm{~h})$ & $(69 \mathrm{~h})$ & (2013) \\
\hline & & & $20^{\circ} \mathrm{C}$ & & & \\
\hline & A. limacinum & GYP & $1 \mathrm{~L} 600 \mathrm{rpm}, 25^{\circ} \mathrm{C} 0.1 \mathrm{vvm}$ & $25.00(72 \mathrm{~h})$ & $34.04(168 \mathrm{~h})$ & This study \\
\hline & BUCHAXM 122 & & $2 \mathrm{vvm}$ & $43.05(48 \mathrm{~h})$ & 34.47 (48 h) & \\
\hline \multirow{3}{*}{ Bubble column } & - & - & - & - & - & - \\
\hline & A. limacinum & GYP & $1 \mathrm{~L} 25^{\circ} \mathrm{C}, 0.1 \mathrm{vvm}$ & $21.15(120 \mathrm{~h})$ & $19.84(168 \mathrm{~h})$ & This study \\
\hline & BUCHAXM 122 & & $2 \mathrm{vvm}$ & $29.50(72 \mathrm{~h})$ & $37.82(72 \mathrm{~h})$ & \\
\hline \multirow{4}{*}{$\begin{array}{l}\text { Internal loop } \\
\text { airlift-type }\end{array}$} & Aurantiochytrium sp. & GY & $3,000 \mathrm{~L}$ & 25 & $52.3(36)$ & Hong et al. (2013) \\
\hline & KRS101 & & & (after $24 \mathrm{~h}$ ) & & \\
\hline & A. limacinum & GYP & $2 \mathrm{~L}, 25^{\circ} \mathrm{C}, 0.1 \mathrm{vvm}$ & $23.41(120 \mathrm{~h})$ & $40.29(168 \mathrm{~h})$ & This study \\
\hline & BUCHAXM 122 & & $1.5 \mathrm{vvm}$ & $36.05(72 \mathrm{~h})$ & $36.93(72 \mathrm{~h})$ & \\
\hline
\end{tabular}

$\mathrm{a}=$ Schizochytrium (now called Aurantiochytrium), Numbers in parentheses following biomass and DHA yields represent fermentation time (hours). 